\title{
Türkiye’deki Eğitim Harcamalarının Değerlendirilmesi
}

\section{Analyze the Examination of Educational Spending In Turkey}

\begin{tabular}{|c|c|}
\hline & Özlem AKIN MART ${ }^{1}$ Sadık KARTAL ${ }^{2}$ \\
\hline $\begin{array}{l}\text { Anahtar Kelimeler } \\
\text { Ĕ̈itim harcamaları, } \\
\text { gayrisafi yurtiçi } \\
\text { hâsıla (GSYH), } \\
\text { OECD ülkeleri. }\end{array}$ & 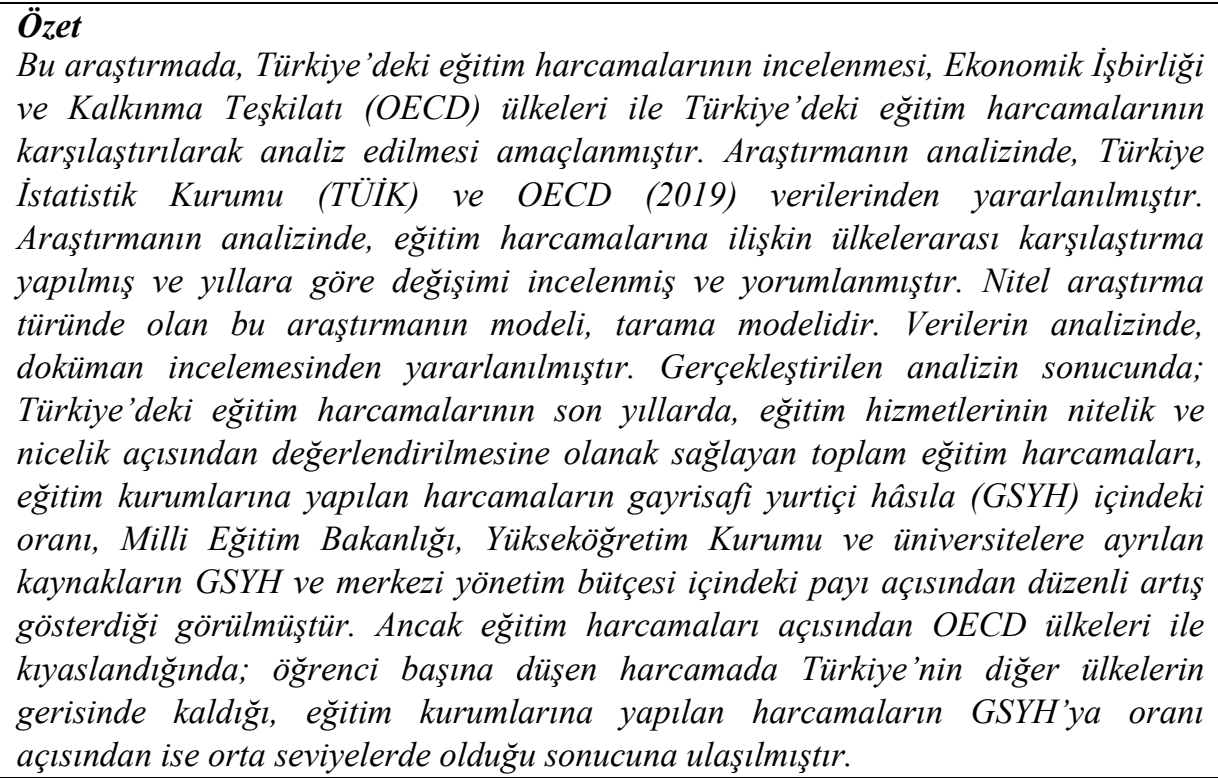 \\
\hline $\begin{array}{l}\text { Education } \\
\text { expenditures, } \\
\text { gross domestic } \\
\text { product (GDP), } \\
\text { OECD countries. }\end{array}$ & $\begin{array}{l}\text { Abstract } \\
\text { In this study, the aim is to analyze the examination of educational spending in Turkey } \\
\text { and comparison between Turkey's and the Organization for Economic Cooperation } \\
\text { and Development (OECD) countries' educational spending. In the analysis of the } \\
\text { research, Turkey Statistical Institute (TSI) and OECD (2019) data were used. In the } \\
\text { analysis of the research, a comparison between countries' education expenditures } \\
\text { and its change by years was examined and interpreted. The model of this research, } \\
\text { which is a qualitative research type, is the survey model. Document analysis was } \\
\text { used in the analysis of the data. As a result of the analysis; it has been observed that } \\
\text { the total expenditure on education in Turkey, which allows the assessment in terms } \\
\text { of quality of educational services and quantity of educational institutions, ratio of } \\
\text { expenditures made to educational institutions in gross domestic product (GDP), } \\
\text { share of the resources allocated to the Ministry of National Education, Higher } \\
\text { Education Institution and universities in GDP and central government budget has } \\
\text { increased regularly in recent years. When Turkey's education expenditures are } \\
\text { compared with OECD countries, it is observed that spending per student in Turkey } \\
\text { falls behind other countries and the ratio of expenditure on educational institutions } \\
\text { in terms of GDP is seen in the middle level. }\end{array}$ \\
\hline
\end{tabular}

\begin{tabular}{ll}
\hline Atıf için: & Akın-Mart, Ö., \& Kartal, S. (2021). Türkiye'deki eğitim harcamalarının değerlendirilmesi. \\
For Citation & Muğla Sitkı Koçman Üniversitesi Eğitim Fakültesi [MSKU Journal of Education], 8(1), 37- \\
& 53. DOI: 10.21666/muefd.7449101
\end{tabular}

Received: 29.05.2020 $\quad$ Accepted: 13.04.2021 $\quad$ Published: 01.05.2021

İnsanoğlunun öğrendiklerini sonraki nesillere aktarma isteğiyle oluşan eğitim kavramının ortaya çıkışı, insanlık tarihi kadar eskidir. İlk olarak temel ihtiyaçların karşılanması gibi basit bilgilerin aktarımı ile

\footnotetext{
${ }^{1}$ Milli Ĕ̆itim Bakanlı̆̆ , oakin2409@gmail.com, ORCID: 0000-0002-1597-1200

${ }^{2}$ Burdur Mehmet Akif Ersoy Üniversitesi, skartal@mehmetakif.edu.tr ORCID: 0000-0001-6049-5656
} 
gerçekleştirilen eğitim, daha sonra bilinçli ve planlı hale dönüşmüştür. Ortaya çıkışı eski toplumlara dayanan eğitim, yaygın olarak "bireyin davranışlarında kendi tecrübesi yoluyla istenilen değişmeyi meydana getirme süreci” (Ertürk, 1975: 12) olarak bilinmektedir. Tezcan'a (1985) göre ise, davranışların şekillendiği ve geliştirildiği süreçler toplamı anlamına gelmektedir. Karaarslan (2005) eğitimi, kültürel ve toplumsal değerleri koruyan ve bu değerlerin gelecek kuşaklara aktarılmasın sağlayan, kalkınmaya ekonomik anlamda katkı sağlayan ve hayati bir önemi olan süreç olarak tanımlamıştır. Hoşgörür ve Gezgin (2005) eğitimin bireyi geliştirip, bireyin hayatına katkı sağlayan mutluluk aracı olarak ifade ederken; Kızıloluk (2007) ise, davranış değiştirme ve insanı tekrar biçimleyen sistem olarak belirtmiştir. Tanımlara bakıldığında; eğitim bir davranış değiştirme ve yeniden şekillendirme sürecidir. Bir bakıma, bireyi yetiştirme faaliyetidir ve nesiller boyunca devamı olan bu yetiştirmenin de bir maliyeti vardır. Bu maliyeti hem devlet hem de bireyler karşılamaktadır ve bunlar genel olarak "eğitim harcamaları" olarak adlandırılmaktadır.

Eğitim harcamaları denildiğinde, eğitimi veren yani Milli Eğitim Bakanlığı, Yüksek Öğretim Kurumu (YÖK) ve Üniversitelerin yaptığı harcamalar akla gelmektedir. Ancak eğitimin yarı kamusal mal ve hizmet olmasından kaynaklı, hem devlete bağlı olan kamu kurum ve kuruluşlarının vermiş olduğu hem de özel sektörün piyasaya sürdügü eğitim hizmetleri (özel okul, dershane vb.) eğitim harcamaları kapsamında ele alınmaktadır (Tiryaki, 2013). Bu nedenle eğitim harcamaları, kamu ve özel eğitim harcamaları olmak üzere iki ayrı sınıfta ele alınabilir. İnsanların toplumsal ihtiyaçlarının karşılanması amacıyla, devlet tarafından gerçekleştirilen harcamalar kamu harcamalarıdır (Akdoğan, 2008: 60). Özel eğitim harcamaları ise, özel eğitim kurumları tarafından yapılan, bireylerin eğitimden faydalanmak için kurumlara ödediği paralar, kurumlardan toplanan yardım, vakıfların yaptığı harcama ve bireylerin bağışları olarak ifade edilebilir (Özgür, 2005:50).

Eğitim harcamalarına ilişkin dünyadaki uygulamalara bakıldığında; ilk ve ortaöğretimde yarı kamusal, yükseköğretimde ise daha çok özel olarak ele alınan eğitim hizmetlerinin kamusal hizmet olarak görülüp, devlet aracılığıyla finanse edildiği söylenebilir (Koçak, 2016). Türkiye'de eğitim hizmeti, önceki dönemlerde devlet tarafından finanse edilmekteyken, zamanla özele kayma görülmüş ve günümüzde de kamu finansmanı ve özel finans kaynakların birlikte kullanıldığı bir hizmet sektörü oluşmuştur (Ulusoy, 2013:10). Bu harcamalar, bu nedenle yarı kamusal olarak kabul edilmekte ve devlet halen destek vermeye devam etmektedir. Devletin eğitim harcamalarına katkısı da eğitim kademelerine göre değişmektedir. Örneğin; temel eğitimde hane halkının karşlayacağ 1 giderler dışındaki diğer giderlerin tümünü üstlenmekteyken, yükseköğretimde öğrencilerden alınan öğrenim ücretleri hariç diğer maliyetlerin büyük kısmını karşılamaktadır (Özer, 2010).

Günümüzde gelişmişliğin göstergesinin eğitime yapılan yatırım olması (Tunç, 1998: 2) eğitime sosyal ve ekonomik yapı içinde kritik bir rol yükler. Eğitim düzeyi ve eğitim harcamaları, ekonomik büyüme, kişisel gelir düzeyi ve gelir dağılımı arasında da karşılıklı bir ilişki söz konusudur. Bu ilişki şu şekilde ifade edilebilir (Yardımcıoğlu, 2012:2).

1. Eğitim hizmetlerine ayrılan kaynakların arttırılması beşeri sermaye yatırımı bağlamında bireylerin verimliliğini arttırır, bireylerin veriminin artması üretimin artmasına, üretimin artması da milli gelirin artmasını sağlar (Eğitim harcamaları ve ekonomik büyüme arasındaki ilişkisi).

2. Bireylerin verimliliği artması kendileri adına daha fazla pay almalarını, bu da kişi başına düşen gelirin artmasını sağlar. Böylelikle uzun vadede gelir dağılımı düzenlenmiş olur. (Eğitim harcamaları ve gelir dağılımı arasındaki ilişki)

3. Milli gelirin artması ekonomik büyümeyi, ekonomik büyümenin artması da eğitim harcamalarına ayrılan payın artmasını sağlar. (Ekonomik büyüme ve eğitim harcamaları ilişkisi)

4. Milli gelir artışı ve ekonomik büyümenin sonucunda bireyler bütçeden daha fazla faydalanır, bu da bireylerin harcamalarında eğitime ayırdıkları miktarın artmasıyla sonuçlanır (Gelir dağılımı ve bireysel eğitim harcamaları).

5. Ekonomik büyüme sektörler arasındaki dağılımını etkiler ve değiştirir, bu da gelir eşitsizliğini doğrudan etkiler (Ekonomik büyüme ve gelir dağılımı ilişkisi),

6. Son olarak, ülkedeki adil gelir dağılımı tüketim, üretim ve yatırıma ilişkin kararları etkiler ve bu da ekonomik büyümede pozitif etkiye sahiptir (Gelir dağılımı ve ekonomik büyüme arasındaki ilişki) 
Sonuç olarak; eğitime yapılan yatırımların bireye ve bireye yapılan yatırımların da topluma fayda sağladığı söylenebilir. $\mathrm{Bu}$ yüzden, kaynakların dağıtımı hususunda toplumsal refah düzeyini sağlayabilmek için devletin sosyal maliyet kısmını yüklenmesi önem arz etmektedir (Karadeniz, Durusoy, \& Köse, 2007: 47). Bu amaçla hem gelişmiş hem de gelişmekte olan ülkelerde eğitime yapılan harcamaların artmakta olduğu görülmekte olup, bu nedenle yurt içi ve yurt dışında gerçekleştirilen eğitim harcamalarına ilişkin yapılan araştırmalar gün geçtikçe artmaktadır.

İlgili literatür incelendiğinde, eğitim harcamalarıyla ilgili çeşitli araştırmaların gerçekleştirildiği söylenebilir. $\mathrm{Bu}$ çalışmaların, eğitimin ekonomik büyümeye etkisine ilişkin (Af̧̧ar, 2009; Akgül \& Koç, 2011; Akınc1, 2017; Barro, 1991; Bayoğlu, 2018; Çalışkan, Karabacak, \& Meçik, 2013; Çetin, 2014; Çondur \& Cömertler-Şimişir, 2017; Dal, 2014; Doğrul, 2009; Eriçok \& Y1lanc1, 2013; Kar \& Ağır, 2003; Kızılkaya \& Koçak, 2014; Koçak, 2016; Pamuk \& Bektaş, 2014; Recepoğlu \& Zuhal, 2017; Sarı \& Soytaş, 2006; Selim, Purtaş, \& Uysal, 2014; Tunç, 1993; Türkmen, 2002; Uçan \& Yeşilyurt, 2016; Yalçınkaya \& Kaya, 2016; Yardımcıŏlu, 2012; Yaylalı \& Lebe, 2011); iktisadi kalkınma ile eğitim arasındaki ilişkiyi inceleyen (Öztürk, 2005) ve eğitim harcamaları ve finansmanları noktasında ülkelerin karşılaştırmasını ele alan (Çalışkan-Maya, 2006; Keller, 2006); kamu gelirleri ve eğitim harcamaları analizini yapan (Tiryaki, 2013); GSYİH ve Türkiye'deki eğitim harcamalarını ele alan (Toprak, Ağcakaya, \& Gül, 2016); farklı y1llarda eğitim harcamalarının analizini gerçekleştiren (Baykal, 2006); OECD ülkeleri ve Türkiye eğitim harcamalarını karşılaştıran (Altundemir, 2008; Arabac1, 2011; Aykut, 2019; Ayrangöl \& Tekdere, 2014; Ceğer, 2018; Çelebi \& Gökmen, 2014; Egeli \& Hayrullaoğlu, 2014; Hüseynov, 2018; Güngör \& Göksu, 2013; Köktaş, 2009; Kurban, 2018; Ömür \& Giray, 2016; Tüleykan \& Parlak, 2018); kamu ve özel kurumlara ilişkin öğrencilerin harcamalarını inceleyen (Arthaud, 2008), Türkiye'de çeşitli kademelerdeki hane halkı eğitim harcamalarını ele alan (Akça, 2002; Ergen, 1999; Karabacak, 2018; Kahveci, 2009; Sakallı, 2010; Sülkü \& Abdioğlu, 2014; Tansel \& Bircan, 2006; TÜİK, 2006; Ulusoy, 2013; Yolcu, 2011) ve üniversitelerin eğitim harcamalarını inceleyen (Çetinkaya, 2017; Ekinci, 2009; Ergen, 1999; Gürez, 2018; Kurt \& Aksoy, 2009; Tarı, Çalışkan, \& Bayraktar, 2006) türde çalışmalar olduğu görülmektedir. $\mathrm{Bu}$ çalışmaların yanında, eğitim harcamaları (özellikle PISA sonuçlarına göre) ile ülkeler arası alınan puan ya da elde edilen başarıyı etkileyen faktörlerin incelenmesi, ülkemizdeki çeşitli sınavlar ve bu sınavlara iliş̧kin eğitim harcamalarına (Kahveci-Serdar, 2009; Konan, Çetin, \& Bozanoğlu, 2018; Yorulmaz, Çolak, \& Ekinci, 2017); OECD rapor verilerinin PISA sonuçlarını nasıl etkilediğine (Aktan \& Akkutay, 2014; Boztunç, 2010; Döş \& Atalmış, 2016; Özer, 2010; Sarıer, 2010) ilişkin çalışmalara da rastlanmaktadır.

Bu bağlamda yapılan çalışmalara katkı sağlamak amacıyla; bu çalışmada eğitim harcamalarına ilişkin son verilerden yararlanılarak, Türkiye'nin eğitim harcamalarının değerlendirilmesi ve OECD ülkeleri ile kıyaslandığında eğitim harcamalarında Türkiye'nin ne düzeyde olduğunun incelenmesi amaçlanmıştır. Bu kapsamda, aşağıdaki amaçlar ve bu amaçlar altındaki sorulara cevap aranmıştır:

1) Türkiye'nin eğitim harcamalarının genel durumu nedir?

a) Türkiye'de eğitime ayrılan kaynakların ve toplam eğitim harcamalarının yıllara göre miktar değişimi ne şekildedir?

b) Türkiye'de eğitime ayrılan kaynakların eğitim kademelerine göre dağglımı ne şekildedir?

c) Türkiye'de toplam eğitim harcamalarının (Milli Eğitim Bakanlığı, Yükseköğretim Kurumu ve üniversitelere ayrılan kaynakların) GSYH ve merkezi yönetim bütçesi içindeki payı nedir?

d) Türkiye'de eğitim bütçesinin merkezi yönetim bütçesine oranı nedir?

e) MEB, YÖK, Üniversiteler ve Yüksek Teknoloji Enstitüleri Bütçelerinin ekonomik sınıflandırmaya göre dağılımı ne şekildedir?

2) Türkiye ve OECD ülkelerinde eğitim harcamaları ne şekildedir? Türkiye ve OECD ülkelerinde eğitim kurumlarına yapılan harcamaların GSHY' ya oranı ve öğrenci başına toplam eğitim harcamaları ne düzeydedir?

\section{Yöntem}

\section{Araştırmanın Modeli}

Nitel araştırma türünde olan bu araştırma, tarama modeline göre yürütülmüştür. Nitel araştırmalar; gözlem, görüşme ve doküman analizi gibi nitel veri toplama tekniklerine başvurulan, var olan olay ve 
olguların hiçbir müdahale etmeden kendi doğal ortamında gerçekçi ve bütüncül bir yaklaşımla incelenen araştırmalardır (Yıldırım \& Şimşek, 2013). Tarama modelindeki amaç da, değiştirmeye kalkmadan gözlem yapmak (Karasar, 2015:77), daha sonra yorumlamak ve değerlendirmektir (Yıldırım \& Şimşek, 2013). Bu çalışmada da; Türkiye'nin genel eğitim harcamaları ve Türkiye ve OECD ülkelerinin eğitim harcamaları araştırmacı tarafından analiz edilmiş ve araştırma soruları dâhilinde belirlenen belirli ölçütlerde incelenmiş ve yorumlanmıştır.

\section{Verilerin Kaynağı ve Analizi}

Çalışmada incelenen veriler, OECD tarafından yıllık yayınlanan OECD (2019) ve Türkiye İstatistik Kurumu (TÜİK) (2018) tarafından yayınlanan Eğitim Harcamaları İstatistiklerinden elde edilmiştir. Ülkelerarası karşılaştırma yapılması ve yıllara göre değişimin incelenmesi açısından 2000 ile 2016 verileri tablolaştırılmış ve yorumlanmıştır. Verilerin analizinde, doküman incelenmesinden yararlanılmıştır. Prior (2003), dokümanlardan sosyal bilimlere ilişkin birçok çalışmada belirli sınırlar dâhilinde yararlanıldığını belirtmektedir. Doküman incelemesi, "araştırılması hedeflenen olgu veya olgular hakkında bilgi içeren yazılı materyallerin analizini kapsar" (Yıldırım \& Şimşek, 2013). Bailey (1982) doküman incelemesinin 7 boyuttan oluşan güçlü yönlerini şu şekilde ifade etmiştir: kolay ulaş1lamayacak özneler, doküman incelemesinde gözlem veya görüşmelerdeki gibi tepkiselliğin olmaması, uzun süreli analiz imkânı olması, örneklem büyüklüğünün geniş olması, araştırmacının bireysel ve özgün olması, harcanacak zaman ve emeği en aza indirmesi yönünden göreli düşün maliyetin olması, kullanılacak belgelerin iyi düzenlenmiş ve incelenmiş olması yönünden nitelikli olması. Bu çalışmada da, eğitim harcamaları istatistikleri verileri araştırma soruları kapsamında sistematik olarak ele alınmıştır. Türkiye'ye ilişkin bazı veriler eksiktir ancak yine de resmi sitede yayımlanan veriler dışına çıkılmaması adına başka kaynaklardan yararlanılmamıştır.

\section{Bulgular}

Bu bölümde öncelikle Türkiye'deki eğitim harcamalarının son yıllardaki genel durumu incelenmiş, daha sonra Türkiye ve diğer OECD üyesi ülkelerdeki eğitim harcamalarının 2000 ile 2016 yılına ilişkin analizi gerçekleştirilmiştir.

\section{Türkiye'deki Eğitim Harcamalarının Genel Durumu}

Bu bölümde sırasıyla, Türkiye'de eğitime ayrılan kaynakların ve toplam eğitim harcamalarının yıllara göre miktarındaki değişim, bu değişimin eğitim kademelerine göre dağılımı, toplam eğitim harcamalarının (Milli Eğitim Bakanlığı, Yükseköğretim Kurumu ve üniversitelere ayrılan kaynakların) GSYH ve merkezi yönetim bütçesi içindeki payı incelenmiştir.

a) Türkiye'de eğitime ayrılan kaynakların ve toplam eğitim harcamalarının yıllara göre miktar değişimi ne şekildedir?

Tablo 1 güncel verilerden yararlanılması amacıyla, Türkiye'deki eğitim harcamalarına ilişkin son 8 yıldaki verilerden yararlanılarak oluşturulmuştur. Tabloda toplam ve öğrenci başına yapılan harcamalar hem TL hem \$ cinsinden ifade edilmiş ve eğitim harcamalarının Gayri Safi Yurtiçi Hasıla'da (GSYH) yeri incelenerek yıllara göre değişimi incelenmiştir. Harcama verilerine oransız olarak bakıldığında, eğitim harcamalarının büyüklükleri hakkında bilgi sahibi olunamayacağı düşüncesiyle, eğitim harcamalarının GSYH ile oranını gösteren verilere de yer verilmiştir.

Tablo 1 incelendiğinde, toplam eğitim harcamalarındaki en yüksek artış oranı 214637 milyon TL eğitim harcamasıyla 2018 yılında görülmüsstür. Eğitim harcamasının GSYH içindeki payına ilişkin 2015 ve 2017 yıllarında bir önceki yıla göre düşüş yaşansa da, bu değer 8 yıl içinde \%5,5'den \%5.8'e çıkmıştır. Öğrenci başına düşen eğitim harcamaları incelendiğinde, genel harcamalarla paralel olarak artış hızının en yüksek 2018 yılında olduğu söylenebilir. Tablo genel olarak değerlendirildiğinde, bu harcamaların yıllara göre artı̧̧ göstermesine rağmen artan GSYH içindeki yeri göz önünde bulundurulduğunda düşük seviyede kaldığı söylenebilir. 
Tablo 1

Türkiye'deki Eğitim Harcamalarına İlişkin Temel Göstergeler

\begin{tabular}{cccccccccc}
\hline & & 2011 & 2012 & 2013 & 2014 & 2015 & 2016 & 2017 & 2018 \\
\hline Toplam Ĕ̆itim & TL & 77.308 & 93.04 & 106. & 122.74 & 135.249 & 160.733 & 176.452 & 214.637 \\
Harcamaları & & & 1 & 041 & 1 & & & & \\
\cline { 2 - 10 } & $\$$ & 46.069 & 51.65 & 55.653 & 56 ii000 & 49.635 & 53.105 & 48.286 & 44.511 \\
& & & 8 & & & & & & \\
\hline Öğrenci Başına & TL & 4.008 & 4.729 & 5.242 & 5.941 & 6.426 & 7.498 & 8.111 & 9.790 \\
\cline { 2 - 9 } Eğitim Harcamas & $\$$ & 2.389 & 2.626 & 2.751 & 2.710 & 2.358 & 2.477 & 2.220 & 2.030 \\
\hline Eğitim & & 5.5 & 5.9 & 5.9 & 6.0 & 5.8 & 6.2 & 5.7 & 5.8 \\
Harcamasinın & & & & & & & & & \\
GSYH İçindeki & & & & & & & & & \\
Yeri (\%) & & & & & & & & & \\
\hline
\end{tabular}

Kaynak: http://www.tuik.gov.tr/PreHaberBultenleri.do?id=30588 Eğitim Harcamaları İstatistikleri, 2018. Sayı: 30588, 18 Aralık 2019.

b) Türkiye'de eğitime ayrılan kaynakların eğitim kademelerine göre dağılımı ne şekildedir?

Eğitim harcamalarındaki artışların hangi eğitim seviyesinden kaynaklandı̆̆ 1 hakkında bilgi sahibi olunabilmesi, eğitim yapısı hakkında daha fazla bilgi sahibi olmayı sağlayacaktır (Ayaz, 2017). Eğitim kademelerindeki eğitim harcamalarına ilişkin bilgilere Tablo 2'de yer verilmiştir.

Tablo 2

Eğitim Kademelerine Göre Eğitim Harcamalart

\begin{tabular}{llllllllll}
\hline $\begin{array}{l}\text { Eğitim } \\
\text { kademesi }\end{array}$ & \multicolumn{7}{c}{ Eğitim Harcaması (Milyon TL) } \\
\hline & 2011 & 2012 & 2013 & 2014 & 2015 & 2016 & 2017 & 2018 & Toplam \\
\hline Okul öncesi & 4.126 & 4.972 & 5.313 & 6.587 & 7.222 & 9.035 & 10.487 & 13.347 & 61.089 \\
İlkokul & 16.938 & 19.153 & 20.354 & 23.542 & 25.530 & 28.227 & 29.211 & 35.004 & 197.959 \\
Ortaokul & 12.506 & 16.446 & 19.369 & 22.621 & 24.243 & 30.168 & 32.599 & 40.267 & 198.219 \\
Ortaöğretim & 18.255 & 22.208 & 26.797 & 30.444 & 34.998 & 42.325 & 50.347 & 62.562 & 287.936 \\
Yükseköğretim & 25.482 & 30.262 & 34.207 & 39.547 & 43.256 & 50.978 & 53.808 & 63.456 & 340.996 \\
\hline
\end{tabular}

Kaynak: http://www.tuik.gov.tr/Start.do Eğitim Harcamaları İstatistikleri, Eğitim Düzeylerine Göre Öğrenci Başına Eğitim Harcaması, 20112018.

Eğitim harcamalarının kademeler içindeki dağılımını içeren Tablo 2'de, toplam eğitim harcamalarındaki en yüksek payın 2018 yılında 63.456 milyon TL ile yükseköğretimde olduğu görülmektedir. Her yıl en düşük payın ise, okul öncesi eğitiminde olduğu söylenebilir. Bütün kademelerdeki harcama payları artış yönündedir. Ancak 2011- 2018 yılları arasındaki eğitim harcamalarına incelendiğinde, yükseköğretim ile ortaöğretim seviyesindeki harcamalarının diğer kademelere göre daha çok artış gösterdiği görülmektedir. Ortaöğretim düzeyindeki eğitim harcamaları, 2018 yılında bir önceki yıla göre 12.000 milyon TL ile en çok artış gösteren harcamalar olmuştur. Ortaöğretim seviyesinin ardından en çok artışın görüldüğü eğitim kademesi, 2018 y1lında 10.000 milyon TL harcama ile yükseköğretim kademesidir.

c) Türkiye'de toplam eğitim harcamalarının (Milli Eğitim Bakanlığı, Yükseköğretim Kurumu ve üniversitelere ayrılan kaynakların) GSYH ve merkezi yönetim bütçesi içindeki payı nedir?

Tablo 3, Türkiye' de 2011-2019 yılları arasında eğitime ayrılan kaynaklar ve bunların GSYH içerisinde oranlarını içermektedir. Eğitim bütçesi Milli Eğitim Bakanlığı, YÖK ve üniversiteler olarak ifade edilmiştir.

Tablo 3'e göre, 2011-2020 yılları arasındaki toplam harcamalar içerisinde en büyük pay Milli Eğitim Bakanlığı' na, ikinci sırada ise YÖK ve üniversitelere ayrılmıştır. 2020 bütçe sunuşuna göre 2011-2019 yılları arasında MEB, YÖK ve üniversitelere genel bütçe içerisinde ayrılan ödenekler genellikle düzenli artış göstermiştir. Ancak ayrılan paylar TL cinsinden artış gösterse de, GSYH ve merkezi yönetim bütçe paylarının dalgalı bir seyir gösterdiği görülmektedir. Tablodaki verilere göre, MEB ve üniversitelere ayrılan ödenek en fazla 2020 yılında (MEB bütçesi 21.284.361.000 TL, üniversite 
bütçesi 5.261.992.000 TL artış) göstermiştir. Merkezi yönetim pay içindeki en büyük artış oranı ise, \% 3.66 ile 2012 y1lina aittir.

Tablo 3

Türkiye'de Eğitim Bütçesi $(2011$ - 2020)

\begin{tabular}{llllc}
\hline Y1llar & MEB & YÖK ve Üniversiteler & \multicolumn{2}{l}{ Toplam Eğitim Bütçesi } \\
\cline { 2 - 5 } & TL & TL & TL & GSYH \% \\
\hline 2011 & 34.112 .163 .000 & 11.503 .927 .500 & 45.776 .282 .500 & 3.52 \\
\hline 2012 & 39.169 .379 .190 & 12.743 .603 .000 & 51.912 .982 .190 & 3.66 \\
\hline 2013 & 47.496 .378 .650 & 15.227 .760 .500 & 62.724 .139 .150 & 4.00 \\
\hline 2014 & 55.704 .817 .610 & 16.939 .010 .000 & 72.643 .827 .610 & 4.16 \\
\hline 2015 & 62.000 .248 .000 & 18.493 .252 .000 & 80.493 .500 .000 & 3.44 \\
\hline 2016 & 76.354 .306 .000 & 23.590 .696 .000 & 99.945 .002 .000 & 3.83 \\
\hline 2018 & 85.048 .584 .000 & 25.620 .450 .000 & 110.669 .034 .000 & 3.65 \\
\hline 2019 & 92.528 .652 .000 & 27.761 .363 .000 & 120.290 .015 .000 & 3.49 \\
\hline 2020 & 113.813 .013 .000 & 33.023 .355 .000 & 146.836 .368 .000 & 3.30 \\
\hline
\end{tabular}

Kaynak: http://sgb.meb.gov.tr/ Milli Eğitim İstatistikleri, Örgün Eğitim, 2019-20: 180.

d) Türkiye'de eğitim bütçesinin merkezi yönetim bütçesine oranı nedir?

Eğitim harcamalarındaki artış düzeyinin yeterliliğine ilişkin yorum yapılabilmesi için, merkezi eğitim bütçesinin incelenmesi gerekmektedir. Tablo 4, Türkiye'de eğitime ayrılan kaynakların merkezi yönetim bütçesi içerisindeki paylarının 2011 ve 2020 yılları arasındaki değişimini ifade etmektedir.

Tablo 4'deki verilere göre, Türkiye'deki merkezi yönetim bütçesi geçmişten bugüne doğru sürekli artış gösterdiği söylenebilir. Eğitime aktarılan toplam bütçe de benzer şekilde düzenli olarak artmaktadır. Toplam eğitim bütçesinin merkezi yönetim bütçesi içindeki payı 2011'den 2016 yılına kadar olan 6 yıllık dönemde düzenli bir artış gösterirken, 2018 yılından itibaren düşüşe geçtiği söylenebilir.

Tablo 4

Türkiye'de Eğitim Bütçesinin Merkezi Yönetim Bütçesine Oranı (2011- 2020)

\begin{tabular}{llll}
\hline Y1llar & $\begin{array}{c}\text { Merkezi Yönetim } \\
\text { Bütçesi }\end{array}$ & $\begin{array}{l}\text { Toplam Eğitim } \\
\text { Bütçesi }\end{array}$ & $\begin{array}{l}\text { Top. Eğitim Bütçesinin } \\
\text { Merkezi Yönetim } \\
\text { Bütçe Oranı } \%\end{array}$ \\
\hline 2011 & 312.572 .607 .330 & 45.616 .090 .500 & 14.59 \\
\hline 2012 & 350.898 .317 .817 & 51.912 .982 .190 & 14.79 \\
\hline 2013 & 404.045 .669 .000 & 62.724 .139 .150 & 15.52 \\
\hline 2014 & 434.995 .765 .000 & 72.643 .827 .610 & 16.70 \\
\hline 2015 & 472.943 .000 .000 & 80.493 .500 .000 & 17.52 \\
\hline 2016 & 570.507 .000 .000 & 99.945 .002 .000 & 17.15 \\
\hline 2017 & 645.124 .000 .000 & 110.669 .034 .000 & 15.77 \\
\hline 2018 & 762.753 .000 .000 & 120.290 .015 .000 & 15.28 \\
\hline 2019 & 960.976 .000 .000 & 146.836 .368 .000 & 14.75 \\
\hline
\end{tabular}

Kaynak: http://sgb.meb.gov.tr/ Milli Eğitim İstatistikleri, Örgün Eğitim, 2019-20: 190.

e) MEB, YÖK, Üniversiteler ve Yüksek Teknoloji Enstitüleri Bütçelerinin ekonomik sınıflandırmaya göre dağılımı ne şekildedir?

Çalışmada genel olarak eğitim harcamalarının incelenmesini ardından, bu harcamaların kendi içindeki ekonomik sınıflandırmaya göre dağılımının incelenmesine de yer verilmiştir. Tablo 5'te 2019-2020 yıllarındaki MEB ve YÖK bütçelerinin ekonomik sınıflandırmaya göre dağılımı yer almaktadır. 
Tablo 5 .

2019-2020 Yıllarında MEB, YÖK, Üniversiteler ve Yüksek Teknoloji Enstitüleri Bütçelerinin

Ekonomik Sinıflandırmaya Göre Dağılımı

\begin{tabular}{ccccc}
\hline Ödenek Türü & \multicolumn{2}{c}{ MEB Bütçesi } & \multicolumn{2}{c}{$\begin{array}{c}\text { YÖK, Üniversiteler, Yüksek } \\
\text { Teknoloji Enstitüleri Bütçesi }\end{array}$} \\
\cline { 2 - 5 } & 2019 & 2020 & 2019 & 2020 \\
\hline Personel Giderleri & 81.622 .485 .000 & 91.467 .345 .000 & 22.719 .121 .000 & 25.031 .119 .000 \\
\hline $\begin{array}{c}\text { Sos. Güv. Kur. Dev. Pir. } \\
\text { Giderleri }\end{array}$ & 13.299 .983 .000 & 14.367 .680 .000 & 3.536 .535 .000 & 3.996 .037 .000 \\
\hline $\begin{array}{c}\text { Mal ve Hizmet Alım } \\
\text { Giderleri }\end{array}$ & 10.038 .497 .000 & 9.956 .271 .000 & 2.165 .469 .000 & 2.379 .335 .000 \\
\hline Cari Transferler & 3.265 .157 .000 & 3.739 .169 .000 & 936.352 .000 & 1.026 .914 .000 \\
\hline Sermaye Giderleri & 5.558 .886 .000 & 5.836 .918 .000 & 3.665 .878 .000 & 3.712 .335 .000 \\
\hline Sermaye Transferler & 28.005 .000 & 29.479 .000 & - & - \\
\hline Toplam & 113.813 .013 .000 & 125.396 .862 .00 & 33.023 .355 .000 & 36.145 .740 .000 \\
\hline & & 0 & & \\
\hline
\end{tabular}

Kaynak: http://sgb.meb.gov.tr/ Milli Eğitim İstatistikleri, Örgün Eğitim, 2019-20: 184-195.

Tablo 5'e göre, Milli Eğitim Bakanlığı ve YÖK, üniversiteler ve Yüksek teknoloji enstitülerine yapılan eğitim harcamalarının büyük çoğunluğu personel giderlerine ayrıldığı söylenebilir. Tabloya göre, 2020 yılında MEB'e yapılan eğitim harcamalarının \%73'ü; YÖK, üniversiteler ve İleri teknoloji enstitülerine yapılan eğitim harcamalarının ise \%69'u personel giderlerine, her iki kurumun \%11'i sosyal güvenlik kurumlarına devletin ödediği prim giderlerine ayrılmaktadır. MEB'e ayrılan harcamaların \%8'i mal ve hizmet alım giderleri, \%5'i sermaye giderleri, geri kalan kısmı da sermaye transferlerine aktarılmaktadır. YÖK, üniversiteler ve İleri teknoloji enstitülerine yapılan eğitim harcamalarından ise, \%7'si mal ve hizmet alım giderleri, \%3'ü cari transferler, \%10'u ise sermaye giderlerine aktarılmaktadır.

\section{Türkiye ve OECD Ülkelerinde Eğitim Harcamaları Karşılaştırması}

Türkiye'nin de üyesi olduğu OECD ülkeleri hem gelişmiş hem de gelişmekte olan ülkelerden oluşmaktadır. Türkiye'deki eğitim harcamaları konusunda izlenen politika ve uygulamaları değerlendirmek için bu bölümde; eğitim kurumlarına yapılan harcamaların GSHY' ya oranı ve öğrenci başına toplam eğitim harcamaları gibi göstergeler temel alınarak Türkiye ve diğer OECD ülkelerin karşılaştırması analiz edilip değerlendirilmiştir.

Öncelikle OECD (2019) açıklanan son verilerden yararlanılarak, OECD ülkelerinde her kademede öğrenci başına harcamalar değerlendirilmiş ve yorumlanmıştır. Çünkü farklı eğitim düzeylerinde kaynakların tahsis edilişi farklılık göstermektedir ve bunların incelenmesi eğitim hizmetlerinin ne şekilde sunulduğuna ilişkin bilgi vermektedir (OECD, 2019). Tablo 6'da eğitim kurumları tarafindan yıllık öğrenci başına yapılan harcamalara ilişkin 2016 yılına ait veriler yer almaktadır.

Tablo 6'da yer alan bilgiler doğrultusunda, OECD ülkelerinin ilköğretim düzeyindeki ortalama 8.470 dolardır. İlköğretim düzeyinde OECD ortalamasının altında kalan 16 ülkenin içinde sondan üç sırada Meksika, Kolombia ve Türkiye yer almaktadır. Türkiye'nin ilköğretim düzeyine yapılan eğitim harcaması sadece 4.168 dolar olmakla birlikte, bu değer OECD ortalamasının neredeyse yarısı değerindedir. Öğrenci başına eğitim harcamasında ilköğretim seviyesine en yüksek payı ayıran ülke, 17.913 dolar harcamayla Lüksemburg' tur. Ortaöğretim düzeyindeki eğitim harcamaları OECD ülkeleri ortalaması 9.968 dolardır. 16 ülkenin OECD ortalamasının altında kaldığı ve Türkiye'nin de 4.659 dolar düzeyindeki eğitim harcamasıyla son sıralarda yer aldığı görülmektedir. İlköğretim kademesindeki gibi, ortaöğretime de en yüksek harcamay1 21.464 dolar ile Lüksemburg'un ayırdığ görülmektedir. Yükseköğretim düzeyi incelendiğinde, ilk ve ortaöğretime ayrılan eğitim harcamalarına göre öğrenci başına eğitim harcama miktarlarında büyük artış olduğu görülmektedir. Genel olarak, dikkate alınan ülkelerde ilk ve ortaöğretime benzer miktarda pay ayrıldığı görülmekle birlikte, bu pay bazı ülkelerde iki katına çıkmıştır. Son on yılda, yükseköğretim için özel fonların daha fazla kullanılmasının, bu seviyedeki harcamaların tahsisini alt kademelere kıyasla değiştirdiği ifade edilmektedir (OECD, 2019). Yükseköğretim için öğrenci başına eğitim harcamalarında yine 48.407 dolar ile Lüksemburg ilk sırayı alırken; ikinci sırayı 30.165 dolarlık harcama ile ABD almaktadır. 
OECD ortalamanın altında 18 ülkenin kaldığ 1 ve Türkiye'nin 10.519 harcamayla yine son siralarda olduğu söylenebilir.

Tablo 6.

Eğitim Kurumları Tarafindan Yıllık Öğrenci Başı Yapılan Harcamalar (2016,\$)

\begin{tabular}{|c|c|c|c|c|}
\hline & İlköğretim & Ortaöğretim & Yükseköğretim & $\begin{array}{l}\text { Eğitimin Tüm } \\
\text { Seviyeleri }\end{array}$ \\
\hline Avustralya & 10.013 & 11.651 & 16.170 & 10.574 \\
\hline Avusturya & 12.299 & 16.313 & 18.332 & 14.345 \\
\hline Belçika & 10.646 & 13.603 & 18.169 & 12.233 \\
\hline Kanada & 9.207 & 13.856 & 23.700 & 12.116 \\
\hline Şili & 5.371 & 5.278 & 9.769 & 6.468 \\
\hline Kolombia & 3.323 & 3.066 & 5.787 & - \\
\hline Çek Cumhuriyeti & 5.104 & 8.425 & 10.009 & 6.857 \\
\hline Estonya & 6.872 & 6.887 & 12.909 & 7.429 \\
\hline Finlandiya & 9.447 & 10.427 & 17.541 & 10.099 \\
\hline Fransa & 7.603 & 12.100 & 16.173 & 10.352 \\
\hline Almanya & 8.960 & 12.268 & 17.429 & 10.994 \\
\hline Yunanistan & 5.973 & 6.779 & - & - \\
\hline Macaristan & 5.454 & 7.174 & 11.288 & 7.345 \\
\hline İzlanda & 11.757 & 11.578 & 14.551 & - \\
\hline İrlanda & 8.468 & 9.948 & 13.237 & 9.034 \\
\hline İsrail & 8.498 & 8.330 & 11.153 & 8.117 \\
\hline İtalya & 7.991 & 9.193 & 11.589 & 8.507 \\
\hline Japonya & 8.978 & 11.219 & 19.191 & \\
\hline Kore & 11.029 & 12.370 & 10.486 & 10.586 \\
\hline Letonya & 6.453 & 6.761 & 7.449 & 6.508 \\
\hline Litvanya & 6.053 & 5.653 & 7.701 & 5.790 \\
\hline Lüksemburg & 17.913 & 21.464 & 48.407 & 20.323 \\
\hline Meksika & 2.961 & 3.167 & 7.347 & 3.435 \\
\hline Hollanda & 8.609 & 13.006 & 19.513 & 11.422 \\
\hline Y. Zelanda & 8.287 & 10.467 & 14.933 & 9.951 \\
\hline Norveç & 12.619 & 14.860 & 21.993 & 13.819 \\
\hline Polonya & 6.808 & 7.124 & 8.977 & 6.976 \\
\hline Portekiz & 7.689 & 9.999 & 11.014 & 8.835 \\
\hline Slovakya & 6.922 & 6.551 & 11.413 & 7.067 \\
\hline Slovenya & 8.621 & 8.487 & 11.257 & 8.633 \\
\hline İspanya & 7.653 & 9.502 & 12.614 & 8.772 \\
\hline İsveç & 11.338 & 11.892 & 24.341 & 11.480 \\
\hline Türkiye & 4.168 & 4.659 & 10.519 & 5.278 \\
\hline Birleşik Kr. & 11.188 & 10.963 & 23.771 & 12.203 \\
\hline $\mathrm{ABD}$ & 12.184 & 13.845 & 30.165 & 16.151 \\
\hline OECD ortalaması & 8.470 & 9.968 & 15.556 & 9.732 \\
\hline
\end{tabular}

Kaynak: OECD (2019), Education at a Glance 2019: OECD Indicators, OECD Publishing, Paris, s. 274.

Genel olarak yorum yapabilmek için; ilköğretim, ortaöğretim ve yükseköğretim olmak üzere üç eğitim düzeyinin ortalamalarını alan öğrenci başına yapılan toplam yıllık eğitim harcamaları incelenmiştir. Tüm eğitim kademelerinde ortalama olarak en çok harcama yapan OECD ülkesi 20.323 dolar ile Lüksemburg' tur. Lüksemburg 'tan sonra ise en çok harcamasına sahip ülkeler ABD, Avusturya, Belçika, Kanada ve Norveç’tir. Türkiye'nin her eğitim seviyesine yapmış olduğu öğrenci başına toplam yıllık harcamalar dikkate alındığında, OECD ülkeleri arasında son sıralarda yer aldığını göstermektedir. İlköğretimden yükseköğretime kadar yapılan eğitim harcamalarının ortalamas 5.278 dolar olmakla birlikte, bu miktarla Türkiye'nin son sıralarda yer aldığı görülmektedir.

Ülkelerin kişi başına milli gelir düzeyleri hakkında bilgi sahibi olunmadan, ülkelerin eğitime ayırdıkları payların düşük veya yüksek olduğuna ilişkin yorum yapmak tek başına yeterli değildir. Bunun nedeni, kişi başına gayri safi yurtiçi hasılaya (GSYH) göre öğrenci başına eğitim kurumlarına yapılan harcamaların, OECD ülkelerine ilişkin göreceli olarak zenginliklerini dikkate alan bir ölçü 
olmasıdır (OECD, 2019). Bu nedenle, Tablo 7'de ülkelerin 2000 yılı ve 2016 yılına ait veriler kullanılarak; yükseköğretim ve öncesi eğitim kademelerindeki ve eğitimin tüm seviyelerindeki yapılan harcamaların ortalamasının GSYH'ye oranı yüzde cinsinden tablo halinde özetlenmiş ve yorumlanmıştır.

OECD ülkelerinin eğitim harcamaları içerisinde ilkokul, ortaokul ve lise eğitimi için ülkelerin GSYH'dan ayırdıkları payın ortalamasının, 2000 yılında \%3.5 ve 2016 yılında \% 3.6 olarak yaklaşık olarak aynı seviyede kaldığı söylenebilir. OECD ülkeleri arasında GSYH'dan ilk, orta ve lise eğitimine en yüksek pay ayıran ülkeler arasında 2000 yılında \% 5'e yakın oranlarla sirasıyla İzlanda, İsrail ve Şili'nin geldiği görülmektedir. 2000 y1lında en düşük paya sahip olan ülkelerin ise Slovakya, Japonya, Macaristan ve Yunanistan olduğu; Türkiye'nin ise en son sırada yer aldığı söylenebilir.

Tablo 7.

OECD Ülkelerinde Eğitim Kurumlarına Yapılan Harcamaların GSHY'ya Oranı (\%)

İlkokul+Ortaokul+Lise $\quad$ Yükseköğretim $\quad$ Eğitim tüm seviyeleri
Eğitim Düzeyi

\begin{tabular}{|c|c|c|c|c|c|c|}
\hline & 2000 & 2016 & 2000 & 2016 & 2000 & 2016 \\
\hline Avustralya & 4.4 & 3.9 & 1.6 & 1.3 & 6.0 & 5.2 \\
\hline Avusturya & 3.9 & 3.1 & 1.2 & 1.3 & 5.7 & 4.4 \\
\hline Belçika & 3.6 & 4.3 & 1.3 & 1.0 & 5.5 & 5.2 \\
\hline Kanada & 3.6 & 3.5 & 2.6 & 1.7 & 6.4 & 5.2 \\
\hline Şili & 4.6 & 3.6 & 2.3 & 2.6 & 7.4 & 6.2 \\
\hline Kolombia & - & 4.0 & - & - & - & - \\
\hline Çek & & & & & & \\
\hline Cumhuriyeti & 3.1 & 2.5 & 0.9 & 0.6 & 4.6 & 3.1 \\
\hline Danimarka & 4.2 & - & 1.6 & - & 6.7 & - \\
\hline Estonya & 3.9 & 2.9 & 1.0 & 1.1 & 5.4 & 4.0 \\
\hline Finlandiya & 3.5 & 3.9 & 1.7 & 1.0 & 5.6 & 4.9 \\
\hline Fransa & 4.3 & 3.7 & 1.1 & 1.0 & 6.1 & 4.7 \\
\hline Almanya & 3.6 & 3.0 & 1.0 & 0.7 & 5.3 & 3.6 \\
\hline Yunanistan & 3.0 & - & 0.9 & - & 4.0 & - \\
\hline Macaristan & 3.0 & 3.2 & 1.1 & 0.9 & 5.0 & 4.1 \\
\hline İzlanda & 4.9 & 4.3 & 0.9 & - & 6.3 & - \\
\hline İrlanda & 3.0 & 2.7 & 1.5 & 0.6 & 4.6 & 3.2 \\
\hline İsrail & 4.7 & 4.5 & 1.9 & 0.9 & 8.2 & 5.4 \\
\hline İtalya & 3.3 & 2.7 & 0.9 & 0.6 & 4.9 & 3.3 \\
\hline Japonya & 2.9 & 2.7 & 1.1 & - & 4.6 & - \\
\hline Kore & 4.0 & 3.7 & 2.6 & 1.4 & 7.1 & 5.0 \\
\hline Lüksemburg & - & 2.8 & - & 0.3 & - & 3.0 \\
\hline Meksika & 3.8 & 3.7 & 1.1 & 1.1 & 5.5 & 4.8 \\
\hline Hollanda & 3.1 & 3.5 & 1.2 & 1.1 & 4.7 & 4.6 \\
\hline Yeni Zelanda & 4.6 & 4.7 & 0.9 & 1.4 & 5.8 & 6.1 \\
\hline Norveç & 3.7 & 4.6 & 1.3 & 1.2 & 5.9 & 5.8 \\
\hline Polonya & 3.7 & 3.2 & 0.8 & 1.0 & 5.2 & 4.1 \\
\hline Portekiz & 4.1 & 3.9 & 1.1 & 0.9 & 5.7 & 4.8 \\
\hline Slovakya & 2.8 & 2.7 & 0.8 & 0.8 & 4.2 & 3.5 \\
\hline Slovenya & - & 3.2 & - & 0.8 & - & 4.1 \\
\hline İspanya & 3.3 & 3.1 & 1.2 & 0.9 & 4.9 & 4.0 \\
\hline İsveç & 4.4 & 3.8 & 1.7 & 0.7 & 6.5 & 4.5 \\
\hline İsviçre & 4.3 & - & 1.1 & - & 5.7 & - \\
\hline Türkiye & 2.4 & 3.5 & 1.0 & 1.6 & 3.4 & 5.1 \\
\hline Birleşik Kr. & 3.8 & 4.4 & 1.0 & 1.4 & 5.3 & 5.8 \\
\hline $\mathrm{ABD}$ & 3.9 & 3.5 & 2.7 & 2.2 & 7.0 & 5.7 \\
\hline OECD ortalaması & 3.6 & 3.5 & 1.7 & 1.1 & 5.9 & 4.5 \\
\hline
\end{tabular}

Kaynak: https://stats.oecd.org/. OECD (2019). Education at a Glance 2019: OECD Indicators, s. 286. https://stats.oecd.org/. OECD (2000). Education at a Glance 2019: OECD Indicators, s. 209.

OECD ülkelerinde eğitime ayrılan bütçenin büyük çoğunluğu ilk, orta ve lise düzeyindeki eğitim kurumlarına ayrılmaktayken, yükseköğretim kurumlarının ikinci sırayı aldığg görülmektedir. OECD 
ortalamasında GSYH' den yükseköğretim kuruluşlarına aktarılan kaynağın 2000 yılında \%1.7 olduğu görülmektedir. Yükseköğretime ilişkin 2000 yılında GSYH'den ayrılan pay bakımından en geride kalan ülkeler Slovakya, Polonya, Çek Cumhuriyet, Yunanistan ve İzlanda iken; üst sıradaki ülkeler ise ABD, Kore ve Kanada'dır. Türkiye'nin ise yine son sıralarda yer aldığ 1 ifade edilebilir. Tüm eğitim seviyelerindeki 2000 yılındaki GSYH'dan ayrılan paya ilişkin ise; OECD ortalamasına göre çok üstte olan ülkeler ABD, Danimarka, Kore ve İsrail iken, ortalamanın oldukça altında kalan ülkeler ise Yunanistan, Slovakya ve Türkiye'dir. 2000 yılında ait verilere göre, GSYH'dan eğitim seviyelerine ayrılan payda Türkiye'nin OECD ülkeleri ile karşılaştırıldığında düşük seviyede kaldığı söylenebilir. 2016 yılına ait OECD ülkelerinin eğitim harcamaları içerisinde ilk, ortaokul ve lise eğitimi için GSYH'dan ayırdıkları payın ortalaması \%3.5; yükseköğretimin pay1 ise \% 1.1'dir. 2000 yılında olduğu gibi OECD ülkelerinde eğitime bütçenin büyük çoğunluğu ilk, orta ve lise düzeyindeki eğitim kurumlarına ayrılmaktayken, yükseköğretim kurumlarının ikinci sırayı aldığ görülmektedir. Eğitim harcamaları içerisinde ilk, ortaokul ve lise eğitimi için GSYH'dan ayırdıkları payın ortalaması OECD ortalamasının oldukça üstünde olan ülkeler Yeni Zelanda, İsrail, Norveç ve Birleşik Krallıkları olduğu görülürken; ortalamanın altında kalıp sıralamanın sonunda yer alan ülkelerin İtalya, Japonya, Çek Cumhuriyeti ve İrlanda'nın olduğu söylenebilir. Türkiye ise, OECD ortalamasıyla aynı değere sahiptir. Yükseköğretime ilişkin 2016 yılında GSYH'den ayrılan payda en geride kalan ülkeler Lüksemburg, İtalya, Çek Cumhuriyet ve İrlanda iken, üst sıradaki ülkeler ise ABD ve Şili'dir. Türkiye'nin 2016 yılında 2000 yılına kıyasla iyileşme gösterdiği söylenebilir. Tüm eğitim seviyelerindeki 2016 yılındaki GSYH'dan ayrılan paya ilişkin OECD ortalamasına göre çok üstte olan ülkeler Yeni Zelanda, Şili, Birleşik Krallıklar ve Norveç iken, ortalamanın oldukça altında kalan ülkeler Lüksemburg, Çek Cumhuriyeti ve İrlanda'dır. 2016 yılı verilerine göre, GSYH'dan eğitim seviyelerine ayrılan payda Türkiye'nin OECD ülkeleri ile karşılaştırıldığında ortalamanın üstünde olduğu söylenebilir.

\section{Sonuç ve Yorum}

Bu çalışmada, Türkiye'nin son yıllardaki eğitim harcamalarının seyrinin ne olduğu ve Türkiye'nin üyesi olduğu OECD ülkeleri ve eğitim harcamalarının karşılaştırılması amaçlanmıştır. Burada OECD ülkeleri ortalamalarıyla karşılaştırılmasında, Türkiye'nin eğitime ilişkin harcamalarının diğer ülkelere kıyasla ne düzeyde olduğunun hakkında bilgi sahibi olunması amaçlanmıştır.

Türkiye'deki eğitim harcamaları genel olarak değerlendirildiğinde; toplam eğitim harcamalarındaki en yüksek artış oranının 2018 yılında olduğu, GSYH içindeki payın 2015 ve 2017 yıllarında bir önceki yıla göre düşüş gösterdiği ancak bu değerin 8 yıl içinde $\% 5.8$ 'e çıktığı görülmüştür. Ayrıca öğrenci başına düşen eğitim harcamalarının artış hızının en yüksek 2018 yılında olduğu belirlenmiştir. Türkiye'deki toplam eğitim harcamaları bir bütün olarak değerlendirildiğinde ise, artan nüfusun yanında harcamaların düşük seviyede kaldığı söylenebilir.

2011-2018 yılları arasındaki eğitim harcamalarının eğitim kademelerindeki dağılımı incelendiğinde; en yüksek payın 2018 yılında yükseköğretime ayrıldığı görülmektedir. Yüksek Öğretim Bilgi Sistemi (2018) öğrenci bilgilerine ait veriler incelendiğinde; 1.492 .277 öğrencinin yükseköğretime kayıt yaptırdığ 1 toplamda ise 7.740 .502 öğrencinin üniversitelerde kayıtlı olduğu göz önünde bulundurulduğunda, bu harcamanın fazla olmasının şaşırtıcı olmadığı söylenebilir. Benzer yorum, 2017 verilerine ait gerçekleştirilen çalışmada da yapılmıştır (Ayaz, 2017). 2005-2013 yılları arası eğitim harcamalarını inceleyen Aykut (2019) Türkiye'de yükseköğretime yönelik yatııımda hızlı bir artışın gözlendiğini belirtmiştir. Yükseköğretimdeki eğitim harcamalarına ilişkin artışın yanında, her yıl en düşük pay okul öncesi eğitimine ayrılmaktadır. Genel olarak eğitim kademeleri değerlendirildiğinde, harcamaların her yıl artış gösterdiği söylenebilir. 2011-2018 y1lları arasındaki harcamalarda, yükseköğretim ile ortaöğretim seviyesinde gerçekleştirilenlerin daha çok artış gösterdiği, 2018 yılında bir önceki yıla göre en çok artış gösteren eğitim kademesinin de ortaöğretim kademesi olduğu sonucuna ulaşılmıştır. Çalışkan, Karabacak ve Meçik (2013) araştırmalarında; ortaöğretim ve yükseköğretim seviyelerinde öğrenci sayısının fazla olmasının ekonomik büyümeyi arttırdığını ve ülkelerin ekonomik büyüme sağlaması için bu kademelere daha fazla eğitim harcaması payı ayırması gerektiğini, böylelikle ortaöğretim ve yükseköğretim seviyelerinde öğrenci sayısının arttırılabileceğini önermiştir. Bu açıdan, bu kademelere yapılan eğitim harcamalarının artış eğiliminde olması Türkiye'nin lehine bir sonuç getirebilir.

2011-2020 yılları arasındaki toplam harcamalar içerisinde en büyük pay Milli Eğitim Bakanlığı'na, ikinci sırada ise YÖK ve üniversitelere ayrıldığı görülmüştür. 2020 bütçe sunuşuna göre 2011-2020 
y1lları arasındaki MEB, YÖK ve üniversitelere genel bütçede ayrılan ödeneklerin genel olarak düzenli artış gösterdiği; bu artış TL cinsinde görülse de, GSYH ve merkezi yönetim bütçe paylarının seyrinde dalgalanmalar olduğu söylenebilir. Bu ödeneklerin, en fazla 2020 yılında (MEB bütçesi 21284361 000 TL, üniversite bütçesi 5261992000 TL artış) gösterdiği görülürken, en büyük artış oranının ise, \%2.66 ile 2012 yılına ait olduğu görülmektedir. Türkiye'deki toplam eğitim bütçesinin merkezi yönetim bütçesi içindeki payı 2011 yılından 2016 yılına kadar artış gösterirken, bu artışın 2016 yılından sonra düşüşe geçtiği söylenebilir.

Gerçekleştirilen harcamaların kendi içindeki ekonomik sınıflandırmaya göre dağılımının incelendiğinde, MEB ve YÖK, üniversiteler ve Yüksek teknoloji enstitülerine yapılan eğitim harcamalarının çoğunun personel giderlerine ayrıldığı görülmüştür. Ayrıca MEB'e yapılan eğitim harcamalarına ilişkin pay çoktan aza doğru sırasıyla personel giderleri, sosyal güvenlik kurumlarına devletin ödediği prim giderleri, mal ve hizmet alım giderleri, sermaye giderleri ve son olarak sermaye transferlerine aktarılmaktadır. YÖK, üniversiteler ve İleri teknoloji enstitülerine yapılan eğitim harcamalarının ilişkin pay çoktan aza doğru sırasıyla personel giderleri, sosyal güvenlik kurumlarına devletin ödediği prim giderleri, sermaye giderleri, mal ve hizmet alım giderleri ve son olarak cari transferlere ayrıldığı söylenebilmektedir.

Türkiye'deki eğitim harcamaları genel olarak değerlendirildiğinde; Türkiye'deki toplam eğitim harcamalarının artış gösterse de genel olarak düşük seviyede kaldığı söylenebilir. MEB, YÖK ve üniversitelere genel bütçede ayrılan ödeneklerin de düzenli artış gösterdiği; ancak GSYH ve merkezi yönetim bütçe paylarının düzenli bir artış içinde olmadığı söylenebilir. Türkiye ekonomisinde sağlıklı bir ekonomik büyüme, ekonomik ve sosyal açıdan kalkınma ve AB kriterlerine uygun duruma gelmesinde eğitim, dolayısıyla eğitim harcamalarının önemli olduğu vurgulanmıştır (Ömür \& Giray, 2016). Milli gelir ve bütçeden ayrılan pay arttıkça sosyal refah düzeyi de yükseleceği (Ayrangöl \& Tekdere, 2014: 9) ; eğitim yatırımları ve ekonomik büyümenin arasında olumlu bir ilişki olması (Afşar, 2009; Eriçok \&Yılanc1, 2013; Landau,1983; Tamang, 2011); ayrıca bu iliş̧inin uzun dönemli olması (Uçan \& Yeşilyurt, 2016) gibi sebeplerle Türkiye'deki eğitim harcamalarına gereken önemin verilerek, bu konu üzerinde durulmasının önemli olduğu ifade edilebilir.

Öğrenci başına yapılan eğitim harcamaları incelendiğinde; tüm eğitim kademelerinde eğitime en çok pay ayıran OECD ülkesi Lüksemburg olurken, Türkiye'nin OECD ülkeleri içinde son sıralarda olduğu görülmüştür. Bu konuda 2016 yılına ait verilerden yararlanılarak daha önce gerçekleştirilmiş olan çalışmada; öğrenci başına yapılan eğitim harcamaların ortalamasında en fazla harcama yapan ülkenin $\mathrm{ABD}$, en az harcama yapan ülkenin Türkiye olduğuna ilişkin bulgulara ulaşılmış, Türkiye'nin OECD ortalamasının altında kaldığı ifade edilmiştir (Ceğer, 2018). Benzer şekilde, Türkiye'nin bu harcamalarda OECD ülkeleri içinde yetersiz kaldığı (Aykut, 2019), artış eğilimi göstermesine rağmen alt sıralarda olduğu (Balc1, 2019; Köktaş, 2009) ilişkin yorumlarda bulunulduğu görülmektedir.

OECD ülkeleri arasında GSYH'dan ilk, orta ve lise eğitimine ayrılan paylar incelendiğinde, Türkiye'nin yine kendi içinde yükseliş içinde olmasına rağmen sıralama olarak OECD ortalaması ile aynı değerde olduğu, ancak yükseköğretime ayrılan kaynağın 2000 yılına kıyasla OECD ortalaması üzerinde bir değere çıttı̆̆1 görülmüştür. Literatür incelendiğinde; Pamuk ve Bektaş (2014) son on yılda Türkiye'de GSYH içinden eğitime ayrılan payın arttığ 1 ancak oransal olarak düşük kaldığını; Ceğer (2018) de 2007-2014 yılları arasındaki eğitim harcamalarında Türkiye'nin GSYH içindeki payının OECD ortalamasının altında kaldığını ve OECD ülkeleri içinde son sırada olan ülkelerden biri olduğunu belirtmiştir. Ömür ve Giray (2016) da Türkiye'deki eğitime ayrılan harcamaların son 10 yıl içinde artış gösterirken, toplam eğitim harcamaları, bu harcamaların GSYH içindeki oranı ve öğrenci başına yapılan harcamalar açısından OECD ülkelerinden düşük olduğunu ifade etmiştir. Bu durumun, GSYH içindeki payın eğitim dışındaki farklı dallara ayrılmasından kaynaklanabileceği düşünülmektedir. Aynı yorum, Ceğer (2018) ve Ergen (1999) tarafından da ifade edilmiştir.

Sonuç olarak; eğitim harcamalarında OECD ülkelerinin ortalamasının artış gösterdiği, Türkiye'nin de ilk, orta ve lise ve yükseköğretime ayrılan payın düzelmekte olduğu, ancak OECD ülkeleri ile kıyaslandığında ortalama değerin üzerinde olamadığı söylenebilir. Aykut (2019) da yükseköğretim açısından Türkiye'nin son yıllarda oldukça iyi seviyede bir ilerleme kaydettiğini vurgulamıştır. Türkiye'nin eğitim harcamalarına ilişkin gerçekleştirilen bu çalışmanın sonucunda; eğitim harcamalarına ayrılan kaynaklarının arttırılarak bu konuda gerekli çalışmaların gerçekleştirilmesi, bütçede düzenlemeye gidilerek eğitimin niteliğinin arttırılması önerilebilir. 


\section{Kaynakça}

Afşar, M. (2009). Türkiye'de eğitim yatırımları ve ekonomik büyüme ilişkisi. Anadolu Üniversitesi Sosyal Bilimler Dergisi, 9(1), 85-98.

Akgül, I., \& Koç, S. (2011). Türkiye Cumhuriyeti tarihinde eğitim ve büyüme ilişkisi: Eşik otoregresif yaklaşım. Trakya Üniversitesi Sosyal Bilimler Dergisi, 13(2), 1-36.

Akça, Ş. (2002). Ailelerin ilköğretim kademesinde yaptıkları ĕgitim harcamaları (Ankara ili örneği) (Yayımlanmamış yüksek lisans tezi). Ankara Üniversitesi EğitimBilimleri Enstitüsü, Ankara.

Akdoğan, A. (2008). Kamu Maliyesi. (12. Bask1). Ankara: Gazi Kitabevi.

Akınc1, A. (2017). Türkiye'de eğitim harcamalarının ekonomik büyüme üzerindeki etkisi. Maliye Dergisi, (173), 387-397.

Aktan, O., \& Akkutay, Ü. (2014). OECD ülkelerinde ve Türkiye'de okulöncesi eğitim. Asya Öğretim Dergisi, 2(1), 64-79.

Altundemir, M. E. (2008). Eğitim harcamalarında Türkiye ve OECD ülkeleri. Uluda $\breve{g} \quad$ Üniversitesi İktisadi ve İdari Bilimler Fakültesi Dergisi, XXVII (2), 51- 70.

Arabacı, İ.B. (2011). Türkiye'de ve OECD ülkelerinde eğitim harcamaları. Elektronik Sosyal Bilimler Dergisi, 10(35), 100-112.

Arthaud, K. (2008). Household Expenditure for Children's Education (Unpublished master thes1s). School of Applied Statistics National Institute of Development Administration, Bangkok, Tayland.

Ayaz, B. H. (2017). Türkiye'deki eğitim harcamalarının gelir dăğlımı kapsamında karşıllaştırmalı olarak incelenmesi (Yayımlanmamış yüksek lisans tezi). Çukurova Üniversitesi Sosyal Bilimler Enstitüsü, Adana.

Aykut, N. (2019). Kamu harcaması olarak ę̆itim harcamaları ve finansmanı: Türkiye OECD ülkeleri karşılaştırması (Yayımlanmamış yüksek lisans tezi). Manisa Celal Bayar Üniversitesi Sosyal Bilimler Enstitüsü, Manisa.

Ayrangöl, Z., \& Tekdere, M. (2014). Türkiye ve OECD ülkelerinde yapılan eğitim harcamalarının karşılaştırmalı analizi. Lefke Avrupa Üniversitesi Sosyal Bilimler Dergisi. 5(2): 1-30.

Bailey, K. (1982). Methods of social research, 4th Edition. https://books.google.com.tr/boo $\mathrm{ks}$ ?hl=tr\&lr=\&id=NT8eiiYhIpoC\&oi=fnd\&pg=PR15\&dq=bailey+methods+of +soci \&ots=6eEQRe9Z\&sig=VuFxsVPfGblL7rmXyyDFecilik8\&redir_esc=y\#v=onepage $\mathrm{q}=$ bailey $\% 20$ methods $\% 20$ of $\quad 20$ social $\& \mathrm{f}=$ false $(25.05 .2020)$.

Balc1, G. (2019). Türkiye'de eğitim sisteminin gelişimi ve eğitim harcamalarının ekonomik büyümeye etkisi: OECD ülkeleri ile karşılaştırılması (Yayımlanmamış Yüksek Lisans Tezi). Bandırma Onyedi Eylül Üniversitesi Sosyal Bilimler Enstitüsü, Bandırma.

Barro, R. J. (1991).Economic Growth in a Cross Section of Countries. The Quarterly Journalof Economics, 106(2), 407-443.

Baykal, Ö. (2006). 1980 sonrası Türkiye'de kamusal eğitim harcamalarının analizi (19802003) (Yayımlanmamış Yüksek Lisans Tezi). Çukurova Üniversitesi Sosyal Bilimler Enstitüsü, Adana.

Bayoğlu, N. (2018). Beşeri sermaye göstergelerinden eğitim harcamalarının ekonomik büyüme ile ilişkisi: 1998:Q1-2016:Q2 dönemi Türkiye örneği (Yayımlanmamış yüksek lisans tezi).Karadeniz Teknik Üniversitesi Sosyal Bilimler Enstitüsü, Trabzon. 
Boztunç, N. (2010). Uluslararası öğrenci değerlendirme programı (PISA)'na katılan Türk ögrencilerin 2003 ve 2006 yıllarındaki matematik ve fen bilimleri başarlarının incelenmesi (Yayımlanmamış yüksek lisans tezi). Hacettepe Üniversitesi Sosyal Bilimler Enstitüsü, Ankara.

Büyüköztürk, Ş., Çakmak, K. E., Akgün, Ö. E., Karadeniz, Ş., \& Demirel, F. (2015). Bilimsel araştırma yöntemleri. Ankara: Pegem Akademi Yayınları.

Ceğer, B. (2018). OECD ülkeleri ile Türkiye'nin eğitim harcamalarının karşılaş̧tırılması (Yayımlanmamış yükssek lisans tezi). Hacettepe Üniversitesi Eğitim Bilimleri Enstitüsü, Ankara.

Çalışkan-Maya, İ. (2006). AB sürecinde Türkiye ile AB Ülkeleri eğitim istatistiklerinin karş1laştırmas1. Türk Ĕgitim Bilimleri Dergisi, 4(4), 375-394.

Çalışkan, S., Karabacak, M., \& Meçik, O. (2013). Türkiye'de eğitim-ekonomik büyüme ilişkisi: 19232011 (Kantitatif Bir Yaklaşım). Yönetim Bilimleri Dergisi, 11(21), 29-48.

Çelebi, N., \& Gökmen, B. (2014). Vergi gelirleri ve eğitim harcamaları. Akademik Sosyal Araştırmalar Dergisi, 2(5), 141-164.

Çetin, B. (2014). Ĕgitim ve kalkınma ilişkisi: Türkiye örneği (Yayımlanmamış yüksek lisans tezi). Karamanoğlu Mehmetbey Üniversitesi Sosyal Bilimler Enstitüsü, Karaman.

Çetinkaya, R. (2017). Yükseköğretimin finansmanı; Türkiye’deki yükseköğretimde ĕğitim harcamalarının etkinliğini arttırmaya yönelik bir model önerisi (Yayımlanmamış yüksek lisans tezi). Karatekin Üniversitesi Sosyal Bilimler Enstitüsü, Çankırı.

Çondur, F., \& Cömertler-Şimşir, N. (2017). Türkiye'de eğitim harcamaları, ekonomik büyüme ve genç işsizlik ilişkilerinin analizi. Uluslararası Bilimsel Araştırmalar $\quad$ Dergisi, 2(6), 44-59.

Dal, E. (2014). Ekonomik büyüme ile eğitim harcamalarl ilişkisi: Türkiye üzerine bir uygulama (Yayımlanmamış yüksek lisans tezi). Eskişehir Osmangazi Üniversitesi Sosyal Bilimler Enstitüsü, Eskişehir.

Doğrul, A. N. (2009). Ekonomik büyümede eğitim harcamalarının etkisi: panel veri analizi. Dumlupınar Üniversitesi Sosyal Bilimler Dergisi, (25), 175-184.

Döş, İ., \& Atalmış, E. H. (2016). OECD verilerine göre PISA sınav sonuçlarının değerlendirilmesi. Abant İzzet Baysal Üniversitesi Ĕgitim Fakültesi Dergisi, 16(2), 432-450

Egeli, H., \& Hayrullahoğlu, B. (2014). Türkiye ve OECD ülkelerinde eğitim harcamalarının analizi. Finans Politik \& Ekonomik Yorumlar, 51(593), 93-108.

Ekinci, C. E. (2009). Türkiye'de yükseköğretimde öğrenci harcama ve maliyetleri. Eğitim ve Bilim Dergisi, 34(154), 119-133.

Ergen, H., (1999). Türkiye'de eğitim harcamalarının analizi ve yükseköğretimde maliyetler (Yayımlanmamış yüksek lisans tezi). Hacettepe Üniversitesi Sosyal Bilimler Enstitüsü, Ankara.

Eriçok, R. E., \& Yılancı, V. (2013). Eğitim harcamaları ve ekonomik büyüme ilişkisi: sınır testi yaklaşımı. Bilgi Ekonomisi ve Yönetimi Dergisi, 8(1), 87-101.

Ertürk, S. (1975). Eğitimde program gelişstirme. Ankara: Yelkentepe Yayınları.

Gölpek, F. (2012). Eğitim getirilerinin özel ve sosyal açıdan incelenmesi. Afyon Kocatepe Üniversitesi Iktisadi ve İdari Bilimler Fakültesi Dergisi, 14(1), 43-53.

Güngör, G., \& Göksu, A. (2013). Türkiye'de eğitimin finansmanı ve ülkelerarası bir karşılaştırma. Celal Bayar Üniversitesi I.I.I.B.F. Dergisi, 20(1), 59-72.

Gürbüz, S., \& Şahin, F. (2016). Sosyal bilimlerde araştırma yöntemleri. Ankara: Seçkin Yayıncılık. 
Gürez, M. F. (2018). Üniversite öğrenci harcamalarının analizi ve karşılaştıkları sorunlar hakkında bir araştırma: Şanlıurfa Örneği (Yayımlanmamış yüksek lisans tezi). Hasan Kalyoncu Üniversitesi Sosyal Bilimler Enstitüsü, Gaziantep.

Hoşgörür, V., \& Gezgin, G. (2005). Ekonomik ve sosyal kalkınmada eğitim. Yüzüncü Yıl Üniversitesi, Ĕ̈itim Fakültesi Dergisi, 2(1).

Hüseynov, Y. (2018). Sosyal refah devleti yaklaşımı açısından Türkiye'de 1980 sonrası eğitim harcamalarının gelişimi: Türkiye-OECD Ülkeleri üzerine bir karşılaştırma (Yayımlanmamış yüksek lisans tezi). İstanbul Üniversitesi Sosyal Bilimler Enstitüsü, İstanbul.

Kahveci, S. S. (2009). Ortaöğretim kurumlarına geçiş sisteminde uygulanan sinavların ailelere maliyetinin ailelerin toplam eğitim harcamaları içindeki payı (Yayımlanmamış yüksek lisans tezi). Gazi Üniversitesi Eğitim Bilimleri Enstitüsü, Ankara.

Kar, M., \& Ağır, H. (2003). Türkiye'de beşeri sermaye ve ekonomik büyüme: Nedensellik testi. II. Ulusal Bilgi, Ekonomi ve Yönetim Kongresi Bildiriler Kitab1, 181-190.

Karaarslan, E. (2005). Kamu kesimi eğitim harcamalarının analizi. Maliye dergisi, 149(42), 36-73.

Karabacak, T. (2018). Türkiye'de hane halklarının eğitim harcamalarını etkileyen faktörlerin belirlenmesi (Yayımlanmamış yüksek lisans tezi). Atatürk Üniversitesi Fen Bilimleri Enstitüsü, Erzurum.

Karadeniz, O., Durusoy, S., \& Köse, S. (2007). Avrupa Birliği yolunda Türkiye'de eğitim ve beşeri sermaye. Ankara: Gazi Kitabevi.

Karasar, N. (2015). Bilimsel Araştırma Yöntemi. Ankara: Nobel Yayınevi.

Keller, K. R. I. (2006a). Investment in primary, secondary, and higher education and the effects on economic growth. Contemporary Economic Policy. 24(1), 18-34.

Kızılkaya, O., \& Koçak, E. (2014). Kamu eğitim harcamaları ve ekonomik büyüme ilişkisi: seçilmiş OECD ülkeleri üzerine bir panel veri analizi. Ekonomi Bilimleri Dergisi, 6(1), 17-32.

Kızıloluk, H. (2007). Ekonominin eğitimin amaçları ve içeriği üzerindeki etkileri. C. Ü. İktisadi ve İdari Bilimler Dergisi. 8(1), 21-30.

Koçak, A. (2016). Eğitim harcamaları ve ekonomik büyüme ilişkileri: Türkiye ve G8 ülkeleri üzerine bir uygulama (Yayımlanmamış yüksek lisans tezi). Hasan Kalyoncu Üniversitesi Sosyal Bilimler Enstitüsü, Gaziantep.

Konan, N., Çetin, R. B., \& Bozanoğlu, B. (2018). Pisa'da başarılı olan ülkelerin eğitim finansmanının uluslararası göstergeler 1şı̆̆ında analizi. Scientific Educational Studies, 2(1), 56-70.

Köktaş, M. A. (2009). Türkiye'de hane halkı eğitim harcamaları analizi (Yayımlanmamış yüksek lisans tezi). Ankara Üniversitesi Sosyal Bilimler Enstitüsü, Ankara.

Kurban, S. (2018). OECD "bir bakışta eğitim raporu 2017" bağlamında Türkiye'de finans ve insan kaynakları yatırımlarının değerlendirilmesi. Akademik Sosyal Araştırmalar Dergisi, 6(68), 437-452.

Kurt, A. İ., \& Aksoy, H. H. (2009). Eğitim maliyeti: Ankara Üniversitesi Eğitim Bilimleri Fakültesi'nde eğitim maliyeti üzerine bir araştırma. Ankara Üniversitesi, Eğitim Bilimleri Fakültesi Dergisi, 42 (2), 1-26.

Landau, D. (1983). Hükümet harcamaları ve ekonomik büyüme: Ülkeler arası bir çalışma. Southern Economic Journal, 49(4),783-792.

MEB, SGB (2015). http://sgb.meb.gov.tr/ Milli Eğitim İstatistikleri, Örgün Eğitim, 2015-16.

MEB (2019). TC. Milli Eğitim Bakanlığı Strateji Geliştirme Başkanlığ1, Milli Eğitim Bakanlı̆ğ 2019 Yllı Bütçe Sunuşu, 17.12.2019. 
OECD (2000), Education at a Glance 2019: OECD Indicators, OECD Publishing, Paris. https://stats.oecd.org/ adresinden erișilmiștir (25.05.2020).

OECD (2019), Education at a Glance 2019: OECD Indicators, OECD Publishing, Paris. https ://doi.org/10.1787/f8d7880d-en (25.05.2020).

Ömür, Ö. M., \& Giray, F. (2016). Kamusal mal ve hizmet olarak eğitim hizmeti ve harcamalar1: Türkiye ve diğer OECD ülkeleri karşılaştırması. Celal Bayar Üniversitesi Sosyal Bilimler Dergisi, 14(4), 129-160.

Özer, R. (2010). Türkiye'de 1990 sonrası yapılan eğitim harcamalarının bütçe politikaları çerçevesinde incelenmesi (Yayımlanmamış yüksek lisans tezi). Afyon Kocatepe Üniversitesi Sosyal Bilimler Enstitüsü, Afyonkarahisar.

Özgür, E. (2005). Türkiye'de kalkınmaya yönelik eğitim politikaları ve eğitim yatırımlarının geri dönüşü (Yayınlanmamış Yüksek Lisans Tezi). Osmangazi Üniversitesi Sosyal Bilimler Enstitüsü, Eskişehir.

Öztürk, N. (2005). İktisadi Kalkınmada Eğitimin Rolü. Sosyoekonomi, 1(1), 27-44.

Pamuk, M., \& Bektaş H., (2014). Türkiye'de eğitim harcamaları ve ekonomik büyüme arasındaki ilişki: ARDL Sınır Testi Yaklaşımı. Siyaset, Ekonomi ve Yönetim Araştırmaları Dergisi, 2(2), 77-90.

Prior, L. (2003). Using documents in social research. Sage.

Recepoğlu, M., \& Zuhal, M. (2017). Türkiye'de eğitim yatırımları ile yerel ekonomik büyüme arasındaki ilişki: Bölgesel dinamik panel nedensellik analizleri. The Journal of International Scientific Researches, 2(8), 1-11.

Sakallı, F., 2010. İlköğretim okulu ögrenci velilerinin ĕgitim harcamaları (Yayımlanmamış yüksek lisans tezi). Gazi Üniversitesi, Eğitim Bilimleri Enstitüsü, Ankara.

Sarı, R., \& Soytaş, U. 2006). Income and Education In Turkey: A Multivariate Analysis. Education Economics, 14(2), 181-196.

Sarıer, Y. (2010). Ortaöğretime giriş sınavları ve PISA sonuçları ışığında eğitimde firsat eşitliğinde olduğu. Ahi Evran Üniversitesi Ĕgitim Fakültesi Dergisi, 11(3), 107-129.

Selim, S., Purtaş, Y., \& Uysal, D. (2014). G-20 ülkelerinde eğitim harcamalarının ekonomik büyüme üzerindeki etkisi. Optimum Ekonomi ve Yönetim Bilimleri Dergisi, 1(2), 93102.

Sülkü, S., N., \& Abdioğlu, Z. (2014). Cepten yapılan eğitim harcamalarının hane halkı gelirine mali yükü: Türkiye için istatistiksel bir analiz. Yönetim ve Ekonomi Araştırmaları Dergisi, (2), 338355.

Tamang, P. (2011). The impact of education expenditure on India's economic growth. Journal of International Academic Research, 11(3), 14-20.

Tansel, A., \& Bircan, F. (2006). Türkiye'de eğitim talebi: Özel ders harcamalarının bir tobit analizi. Eğitimin gözden geçirilmesi ekonomisi, 25 (3), 303-313.

Tarı, R., Çalışkan Ş., \& Bayraktar, Y., (2006) Kocaeli Üniversitesi öğrencilerinin gelir ve tüketim ilişkisi üzerine ekonometrik bir inceleme. Kocaeli Üniversitesi Sosyal Bilimler Enstitüsü Dergisi, 11(1), 168-179.

Tezcan, M. (1985). Eğitim sosyolojisi. Ankara: Ankara Üniversitesi Eğitim Bilimleri Fakültesi Yayınları.

Tiryaki, A. (2013). 1980 sonrası kamu gelirleri ile eğitim harcamaları arasındaki ilişki: Granger nedensellik analizi (Yayımlanmamış yüksek lisans tezi). Gaziosmanpaşa Üniversitesi Sosyal Bilimler Enstitüsü, Tokat. 
Toprak, D., Ağcakaya, S., \& Gül, H. (2016). Sosyal devlet yaklaşımı açısından Türkiye'de 1980 sonrası eğitim harcamalarının analizi. Dokuz Eylül Üniversitesi İktisadi İdari Bilimler Fakültesi Dergisi, 31(1), 123-165.

Tunç, M. (1993). Türkiye'de eğitimin ekonomik kalkınmaya etkisi. Dokuz Eylül Üniversitesi, İ̈BF Dergisi, 8(2), 1-32.

Tunç, M. (1998). Kalkınmada insan sermayesi iç getiri oranı yaklaşımı ve Türkiye nalizi. D.E.ய̈. İ.I. B.F. Dergisi, 13(1), 83-106.

Tüleykan, H., \& Parlak, M. A. (2018). Türkiye'de kamu kesiminin eğitim harcamalarının değerlendirilmesi. Uluslararası Yönetim Eğitim ve Ekonomik Perspektifler Dergisi, 6(2), 3453.

Türkiye İstatistik Kurumu (TÜİK) (2018). Eğitim Harcamaları İstatistikleri, Say1: 30588, 18 Aralık 2019. http://www.tuik.gov.tr/PreHaberBultenleri.do?id=30588 sayfasından erişilmiştir (25.05.2020).

Türkmen, F. (2002). Eğitimin ekonomik ve sosyal faydaları ve Türkiye'de eğitim ekonomik büyüme ilişkisinin araştırılmast: uzmanlık tezi. Devlet Planlama Teşkilatı. Yayın No:2655, DPT Yayınlar1,

Uçan, O., \& Yeşilyurt, H. (2016). Türkiye'de eğitim harcamaları ve büyüme ilişkisi. Niğge Üniversitesi İ.̇.B.F Dergisi, 9(2), 179-185.

Ulusoy, B. (2013). Ailelerin ilköğretim düzeyinde yapmış oldukları hane halkı eğitim harcamaları (Yayımlanmamış yüksek lisans tezi). Kastamonu Üniversitesi Sosyal Bilimler Enstitüsü, Kastamonu.

Yalçınkaya, Ö., \& Kaya, V. (2016). Eğitimin ekonomik büyüme üzerindeki etkileri: düşük, orta ve yüksek gelirli ülkeler üzerinde bir uygulama (1991-2011). Abant İzzet Baysal Üniversitesi Sosyal Bilimler Enstitüsü Dergisi, 16(3), 27-60.

Yardımcıoğlu, F. (2012). Eğitim harcamaları, ekonomik büyüme ve gelir dağılımı ilişkisi (Yayımlanmamış doktora tezi). Sakarya Üniversitesi Sosyal Bilimler Enstitüsü, Sakarya.

Yaylali, M., \& Lebe, F. (2011). Beşerî sermaye ile iktisadi büyüme arasındaki ilişkinin ampirik analizi. Marmara University Journal of the Faculty of Economic \& Administrative Sciences, 30(1), 23-51.

Yıldırım, A., \& Şimşek, H. (2013). Sosyal bilimlerde nitel araştırma yöntemleri. (9. Genişletilmiş Bask1) Ankara: Seçkin Yayınevi.

Yolcu, H. (2011). Hanehalkının eğitim harcamalarını etkileyen etmenler: Kuramsal bir çalışma. Mehmet Akif Ersoy Üniversitesi Sosyal Bilimler Enstitüsü Dergisi, 3(5), 1235.

Yorulmaz, Y. İ., Çolak, İ., \& Ekinci, C. E. (2017). An evaluation of PISA 2015 achievements of OECD countries within income distribution and education expenditures. Turkish Journal of Education, 6(4),169-185.

Yükseköğretim Bilgi Sistemi (2018). 2018-2019 öğretim yıl1 yükseköğretim istatistikleri, öğrenci sayıları özet tablosu. https://istatistik.yok.gov.tr/ (25.05.2020).

\section{Extended Summary}

\section{Introduction}

Education is defined as a process that preserves cultural and social values and ensures that these values are passed on to future generations, contributes to development economically and it has a vital importance. In a way, it is an activity of raising the individual, and this training, which is continuous over the generations, has a cost. This cost is covered by both the state and individuals, and these are commonly referred to as 'education expenditures'. Educational services in Turkey, financed by the 
state in previous periods before, but today the public finance and the service sector where they use private sources of finance has occurred.

Today, the indicator of development is the investment made in education, which gives education a critical role in the social and economic structure. Therefore, it is important for the state to take the social cost in order to ensure the social welfare level in the distribution of resources. In this context, it is aimed to evaluate the educational expenditures in Turkey and compare it with other OECD countries, and investigate the level of education spending in Turkey.

\section{Methodology}

The research, which is a qualitative research type, was conducted according to the scanning model. The purpose of the scanning model is to observe without trying to change it, then to interpret and evaluate. The data examined in this study were obtained from published by Education Expenditure Statistics. The 2000 and 2016 data are tabulated and interpreted. Document analysis was used in the analysis of the data. Documents are used within certain limits in many studies on social sciences.

\section{Findings and Discussion}

When evaluating overall spending on education in Turkey; it was seen that the highest rate of increase in total education expenditures was in 2018, the share in GDP decreased in 2015 and 2017 compared to the previous year, but this value increased to $5.8 \%$ in 8 years. It was determined that the highest rate of increase in education expenditures per student was in 2018. When considered as a whole the total spending on education in Turkey, it can be said that the growing population of the next spending remains at a low level. Allowences in the general budget for MoNE, Higher Education Institution and universities also increased regularly, but it can be said that the shares of GDP and central government budget are not in a steady increase. It was stated that as the national income and the share allocated from the budget increase, the level of social welfare will also increase. This is also a long-term relationship as the reasons given importance to education spending in Turkey, it can be said that it is important to focus on these issues.

When the education expenditures for per student are examined; all levels of education in most OECD countries, Luxembourg is the first in terms of separation for the education and Turkey is in last place in OECD countries. Turkey's inadequate spending in OECD countries were expressed in previous studies. Over the last decade, Turkey has increased the share of GDP allocated to education within states that remain relatively low. As a result of this study; it may be suggested to carry out the necessary studies by increasing the resources allocated to education expenditures, and to increase the quality of education by making adjustments in the budget.

\footnotetext{
*Bu makaleye yazarlar eşit oranda katkı sağlamıştır.
} 